Walking and the Aesthetics of Modernity 

Klaus Benesch • François Specq

Editors

\section{Walking and the Aesthetics of Modernity}

Pedestrian Mobility in Literature and the Arts 


\section{Editors}

Klaus Benesch

Department of English and American

Studies

LMU Munich

Munich, Germany
François Specq

Ecole Normale Superieure de Lyon \&

CNRS (IHRIM)

Lyon, France

ISBN 978-1-137-60282-4

DOI $10.1057 / 978-1-137-60364-7$

ISBN 978-1-137-60364-7 (eBook)

Library of Congress Control Number: 2016952088

(C) The Editor(s) (if applicable) and The Author(s) 2016

This work is subject to copyright. All rights are solely and exclusively licensed by the Publisher, whether the whole or part of the material is concerned, specifically the rights of translation, reprinting, reuse of illustrations, recitation, broadcasting, reproduction on microfilms or in any other physical way, and transmission or information storage and retrieval, electronic adaptation, computer software, or by similar or dissimilar methodology now known or hereafter developed.

The use of general descriptive names, registered names, trademarks, service marks, etc. in this publication does not imply, even in the absence of a specific statement, that such names are exempt from the relevant protective laws and regulations and therefore free for general use. The publisher, the authors and the editors are safe to assume that the advice and information in this book are believed to be true and accurate at the date of publication. Neither the publisher nor the authors or the editors give a warranty, express or implied, with respect to the material contained herein or for any errors or omissions that may have been made.

Cover illustration courtesy of the Bain Collection, Library of Congress

Printed on acid-free paper

This Palgrave Macmillan imprint is published by Springer Nature

The registered company is Springer Science+Business Media LLC New York 


\section{Modern(s) Walking: An Introduction}

If life is a journey through time and space, from early childhood to old age, and from our birthplace to the places where we seek employment, found families, or eventually retire to and pass away, much of that journey will be done on foot or, more precisely, by way of walking. Though rarely questioned as a form of universal movement, walking, as Balzac famously claimed, appears to be at the center of the human condition. An important cultural technique in its own right, walking allows us to interact with the environment in unique ways: through walking we acquire a sense of physical space and we learn how to measure distances, how to distinguish that which is far off from what is immediate and close by. Put another way, walking defines our experience of self and of the world.

It also provides insight into the complex skein of human life itself. While walking, mathematician William Rowan Hamilton finally thought of a formula for the analysis of three-dimensional space, and Karl Marx, perambulating with his son-in-law, Paul Lafargue, through London's Hampstead Heath Park, is said to have envisioned the entire economic system as outlined in the first volume of Das Kapital. ${ }^{1}$ Moreover, writers, artists, and thinkers frequently embraced the slow motion of walking as a powerful tool to undo the limitations and self-alienation imposed by modern capitalist society. ${ }^{2}$ And where resistance to rampant capitalism has become either impossible or futile, as in Cormac McCarthy's postapocalyptic novel The Road (2007), it is through walking that characters retrace the journey of mankind from its early tattered existence in the woods to the more refined stages of human interaction and bonding. If human life, then, has always also been a journey on foot, the history of 
that journey begins with man's (or woman's, for that matter) transformation from a crawling to a walking animal.

\section{In the Beginning Was the Foot}

The shift from quadrupedalism to an upright mode of movement, from crawling, jumping, or galloping to walking, has been a crucial moment in the history of human culture. "The diminution of the olfactory stimuli," Freud argues in Civilization and Its Discontents (1930), "seems itself to be a consequence of man's raising himself from the ground, of his assumption of an upright gait; this made his genitals, which were previously concealed, visible and in need of protection, and so provided feelings of shame in him" (qtd. in Solnit). Since by walking around, the early upright men of central Africa, so-called Homo erectus, disclosed their reproductive organs, the ensuing feeling of shame and guilt, Freud seems to suggest, led to the veiling of the body and, eventually, to the establishing of social etiquette. It also led to a diminution of our sensual experience of the world, thereby instituting a rift between self and other, human and non-human. To have learned how to walk not only allowed early humans to extend their realm of action, from the rain forest to the savanna, but, man's "raising from the ground" and its accompanying replacement of olfactory by mediated, that is, cultural experiences of the world, also marks the beginning of civilization itself. From now on, life has turned into a relentless journey; to be human is to be in motion: in order to "know" the world one has to leave home and hearth, and embark on an exploratory voyage to places elsewhere, unknown and far-off.

Whether the upright gait has been the sole driving force of civilization and the production of culture is, of course, debatable. There is little doubt, however, that walking has always been more than merely a wellcoordinated movement of body parts. As an expression of the human will to explore, interact with, and ultimately transcend the limits of the physical environment, it has served as a motor of progress, a relentless force of change and transformation.

A key moment in the shift from sedentary to mobile forms of life, walking clearly resonates with the modern emphasis on a movement in space. Modern literature is replete with men (less frequently women) walking, with people in motion or in transition from country to city, from home to foreign land, from the well-known to the unknown, from departure to arrival. Quite frequently, its peripatetic characters are far from being 
goal-oriented, that is, they walk for the sake of walking, endlessly and excessively, in order to avoid being stationary, being fettered to place and time. Obsessive walkers abound in modern literature and so does the notion that walking somehow captures the experience of being modern, that it somehow provides insight into the underpinnings of modern life itself.

\section{Wanderlust and/In Modernity}

Predicated on the human body and its finite power resources, the act of walking, however, always also involves a fundamental challenge inherent in modern existence, namely, the problem of how to negotiate, on the one hand, man's extension into space and, on the other, her being rooted in a particular time and place. If the former evokes modernity's mobile lifestyles, the latter relates to an inevitable human emplacement in the environment or, as Merleau-Ponty succinctly put it, to our being there. ${ }^{3}$ Walking thus encapsulates a fundamental paradox of modern life: the need to conjoin forms of being in-motion with a being-there, a being anchored in a particular place and time. Wary of unwonted consequences of mobility and speed, moderns often posit walking as an alternative mode of movement, one that engages both body and soul and, thereby, sublates the tensions inherent in modern society. To comprehend the complex, shifting role of mobility we also have to register its absence, that is, the self-imposed lack or restraint of constant movement. As several of the chapters gathered in this volume emphasize, to not move or to slow down and walk, loiter, or ramble often coincides with anti-modern sentiments and an encompassing antipathy toward modernity at large (see, e.g., the contributions of Gross and Estes).

To alleviate the tensions between mobility and immobility, space and place, progress and stasis, the act of walking takes on particular importance. Significantly, if also somewhat paradoxically, walking has often come to signify a counterspace, a mode of mobile existence that frees the mind from the limitations of history and tradition, thereby empowering the autonomous subject and providing moments of epiphanic insight. Unimpeded by technology and the regulations and laws it necessitates, the act of walking allows to pay close attention to particular places and regions. In so doing walking lends itself readily to notions of rootedness, thereby defying unfettered rapid progress and cultural change. ${ }^{4}$ Moreover, as it slowly moves bodies through spaces, walking allows for an encompassing 
experience, and it enables the individual to resist the demands of family, society, civilization. While walking body and mind join to interact with the environment, and to provide a panoply of ways-intellectual, emotional, bodily - to "take in" and make sense of the world "out there." From the late eighteenth to the twenty-first century walking repeatedly figured as an alternative mode of human existence, one that is outside of the restrictions and limitations of modern life as we know it.

"If you are prepared to leave father and mother, and brother and sister, and wife and child and friends, and never see them again," Thoreau writes in his essay "Walking," "if you have paid your debts, and made your will, and settled all your affairs, and are a free man, then you are ready for a walk" ("Walking" 186). If walking has the power to liberate, for walkers less receptive to the idea of freedom, Thoreau seems to suggest, who have not yet severed ties with society, have not yet freed themselves from the constraints of the marketplace and the dictates of social conventions, the benefits of walking will be limited. Yet those who do will benefit greatly! To transcend the social and economic conditions modern writers, artists, and thinkers often embarked on a journey on foot, a journey by which they hoped to wed past and future, to acknowledge the rootedness of tradition while simultaneously exploring its limits and opening it up toward a malleable, uncertain future. The trajectory and routes of these modern walkers, their journeys through cities, into the wilderness, or across entire continents inform many-if not all —of the 20 essays collected in this volume. Whether they look at novelists, poets, painters, photographers, filmmakers, or simply at tourist walkers, all share an interest in moderns walking, and in the representation of their walks in the arts.

In On Foot: A History of Walking Joseph Amato reminds us that "the act of walking on foot is joined to a time, condition, society, and culture" (2). To take note of who walks, to what gender, age, ethnicity, and class the walker belongs, to take into account what he or she is wearing while walking, and to gauge the landscapes and distances the walker traverses cannot but shed light on a society as a whole, its tensions, attitudes, and the cultural myths on which it is predicated. As mentioned above, this is particularly true for modern, technologically advanced societies where walking has ceased to be the obvious, primary means of movement. The walker who walks out of necessity, either for a lack of means or the absence of alternatives, is less prone to reflect upon why she/he walks than, say, the modern flâneur who, when roaming the city, embarks on a contemplative journey that provides revelatory experiences regarding self and society. 
Though walking always draws attention to the walker, the contributors to this volume are particularly interested in those instances where walking has also become topical, an "objet d'art," or the subject of study, of critical reflection and representation. "Isn't it curious," Balzac famously writes in his Theory of Walking (1833), "that ever since man has walked, no one has asked why he walks, or how, or if he could improve his walking, or what he does when he walks, whether one could not impose his walking, change or scrutinize it -issues that are integral to all the philosophical, psychological or political systems that have occupied the world?" ${ }^{5}$ It is the interface of walking and modern philosophical, psychological, and political systems, of how we experience and make sense of both our individual lives and the world at large that is the focus of the essays collected here.

\section{Modern(s) Walking: Who, Where, and Why?}

While the notion of walking has been explored by a number of authors over the last three decades, the focus of this book is different, both in its scope and in its approach. The existing scholarship fundamentally falls into three types of approaches. Literary studies of walking, which initiated the scholarly interest in this theme in the 1990s, have mainly focused on a poetics of writing as part of a "Romantic tradition," from Wordsworth to the twentieth century (see especially Robinson, Jarvis, Gilbert). Cultural studies of walking rose to prominence in the 2000s, through books with a broader focus on the history and imagination of the act of walking (see especially Solnit, Amato, Nicholson, Gros). Nurturing both, influential essays by Walter Benjamin, Jacques Derrida, and Michel de Certeau have considered the topic from a more theoretical or philosophical perspective.

Even as it refers to those classic studies of walking, this volume has different emphases. As a collection of essays, it covers a wider array of authors and topics than more specialized studies, ranging as it does from eighteenth-century fiction writers and travelers to contemporary film, digital art, and artists' books. And it is concerned with a closer examination of texts and visual art than books with a broad historical, cultural, or theoretical orientation.

The chapters gathered in section I focus on the different ways space is perceived, constructed, and made meaningful through the act of walking. Whether in eighteenth-century narratives, nineteenth-century visions of 
flânerie, or contemporary poetry, walking proves to be deeply connected to different modes of creativity, in which the narrative, the poetical, and philosophical reflections mingle or alternate, but are integral parts of an aspirational and inspirational sense-making activity.

Section II, then, explores how the art of walking is a way of performing space, or a response to what might be described as the theatricality of even our most ordinary experience, not to mention the intricate staging of mobility through virtual spaces, which dramatizes the unstable nature of identities and topologies. Far from warranting any return to standard modes of self-definition, or from enacting any sublimation of tensions, walking here conveys the ambiguities of our being-in-the-world.

While walking is often seen as an antidote to-or a way of balancingthe seemingly overbearing influence of speed in the modern world, the chapters in section III consider how modern authors envision the intersections between walking and disease, madness, and violence. Far from revealing or restoring a sense of order and bodily connection, walking here is linked to the deconstruction of character and disruptive modes of being, in which the walker is, mentally if not physically, distanced from the world, and prone to fear or terror rather than to serene enlightenment. In the end, however, this dissociative practice of walking may brace the individual for the chaotic nature of the modern world.

Finally, the chapters in section IV analyze how walking, in works ranging from the nineteenth century to the contemporary period, is staged in relation to various historical and political issues. It revisits the politics of space and explores and redefines the connection between walking individuals and their communities. Walking is here inherently social and relational, albeit rendered in a mode that is not necessarily consensusoriented, but rather attuned to dissent.

As the chapters demonstrate, walking, far from constituting a simplistic, naïve, or transparent cultural script, allows for complex visions and reinterpretations of man's relation to the modern world, and introduces us to a world of many different and changing realities.

LMU

Klaus Benesch

Munich, Germany

Ecole Normale Supérieure de Lyon \& CNRS (IHRIM) François Specq Lyon, France 


\section{Notes}

1. See Crowe, A History of Vector Analysis; and Solnit, Wanderlust.

2. For modernist Paul Klee, art alone offered a space for non-utilitarian thinking, a space, as he famously puts it in Das pädagogische Skizzenbuch (1925), closely associated with the activity of walking: "[wie] ein Spaziergang, um seiner selbst willen, ohne Ziel" (6) [ "a walk for its own sake, without specific aim," (our translation)].

3. In Phenomenology of Perception Merleau-Ponty claims that spatiality or human spatial existence is "the primary condition of all living perception" (109), and that our sense of being is therefore indelibly linked to the notion of being in space; put another way, being is always also a being there, a form of emplacement.

4. A case in point is Martin Heidegger's "The Pathway," which proffers a multilayered, paradoxical notion of walking, oscillating between movement and stasis, between leaving home and its opposite, the intense involvement with places, roots, and the environment nearby. See Benesch, "Cultural Immobility: Thoreau, Heidegger, and the Modern Politics of Place."

5. "N'est-il pas réellement bien extraordinaire de voir que, depuis le temps où l'homme marche, personne ne se soit demandé pourquoi il marche, comment il marche, s'il marche, s'il peut mieux marcher, ce qu'il fait en marchant, s'il n'y aurait pas moyen d'imposer, de changer, d'analyser sa marche: questions qui tiennent à tous les systèmes philosophiques, psychologiques et politiques dont s'est occupé le monde?” Honoré de Balzac, Théorie de la démarche 260 (our translation). 



\section{ACKNOWLEDGMENTS}

The idea for this book sprang from a conference at the École Normale Supérieure de Lyon in October 2013, titled "The Art of Walking." The editors would like to acknowledge the generous support of this conference by the following organizations: École Normale Supérieure de Lyon (Université de Lyon), LMU (University of Munich), Centre National de la Recherche Scientifique (CNRS-IHRIM), ARC5 (Région Rhône-Alpes). We are particularly grateful for the enthusiasm and meticulous editorial support of Ryan Jenkins and Paloma Yannakakis at Palgrave Macmillan, who not only guided us through the maze of copyright and permission issues but ensured the formal cohesion of this multinational, comparative inquiry into the place of walking in modern aesthetics and intellectual history. Special thanks go to Ursula Heise at University of California, Los Angeles (UCLA), who found the scope and themes of this book worthy to be pursued and encouraged us to submit a preliminary proposal to Palgrave Macmillan. 



\section{Contents}

Part I Poetics

Walking the Streets of London in the Eighteenth Century:

A Performative Art?

Emmanuelle Peraldo

Musing, Painting, and Writing: Walking as an Art in Diderot's Promenade Vernet (Salon de 1767) Juliette Fabre

"Du croisement de leurs innombrables rapports": Baudelaire and De Quincey's flâneurs

Estelle Murail

How Poetry Comes to Him: An Excursion to Gary Snyder's Wild Poetics

Thomas Pughe

Revisiting the American "Walk Poem": A.R. Ammons, Charles

Olson, and Jonathan Williams

Lacy Rumsey 
Marianne Colston's Art of Walking: Gendering the Picturesque in Journal of a Tour in France, Switzerland, and Italy Isabelle Baudino

Following Footprints: Photography, Writing, and the Artist's Book in Art Walking Bridget Sheridan

Wayfaring in the Megacity: Tsai Ming-Liang's Walker and Lav Diaz's Melancholia

Gabrielle Finnane

The Art of Walking in Space and Time: The Quest for London

Tatiana Pogossian

Walking with the World: Toward an Ecological Approach to Performative Art Practice Andrew Goodman

The Art of Walking and the Mindscapes of Trauma in Thomas De Quincey's Autobiographical Works: The Pains of Wandering, the Pains of Remembering Françoise Dupeyron-Lafay

Writing Dromomania in the Romantic Era: Nerval, Collins, and Charlotte Brontë 
A Juggernaut in the Streets of London: Walking as Destructive

Force in R.L. Stevenson's Strange Case of Dr. Jekyll and

Mr. Hyde

Catherine M. Welter

Thomas Wolfe and the Urban Night Prowl: Walking,

Modernism, and Myth

Amélie Moisy

Existential Wanderings in Gus Van Sant's "Walking Trilogy":

Gerry, Elephant, and Last Days

Sophie Walon

Part IV Politics

Perambulating the Village: Henry David Thoreau and the Politics of "Walking"

Julien Nègre

Walking in Wartime: Edith Wharton's “The Look of Paris" Virginia Ricard

Pound, Peripatetic Verse, and the Postwar Liberal Aesthetic Andrew S. Gross

The Art of the "Good Step” in Colm Tóibín's Bad Blood:

A Walk Along the Irish Border (1987)

Marie Mianowski 
xviii CONTENTS

Walking and Technology in the Fiction of Jennifer Egan:

Moving toward the Posthuman

Andrew Estes

Bibliography

Index 


\section{Contributors}

Isabelle Baudino is a senior lecturer at the École Normale Supérieure in Lyons (ENS Lyon) and a member of the IHRIM laboratory (CNRS). She has written numerous articles on British eighteenth-century painting and on the history of the Royal Academy of Arts. She has led an interdisciplinary research project on British women travel narratives and edited the resulting volume, Les voyageuses britanniques an XVIIIe siècle: l'étape lyonnaise dans l'itinéraire du Grand Tour, published in 2015.

Klaus Benesch is Professor of English and American Studies at Ludwig Maximilian University of Munich (LMU Munich). He was a 2004 Mellon Fellow at the Harry Ransom Humanities Research Center of the University of Texas (Austin), and has taught at the University of Massachusetts (Amherst), Weber State University (Utah), École normale supérieure (Lyon), the University of Bordeaux, Montaigne, and at Venice International University (San Servolo). From 2006 through 2013, he was Director of the Bavarian American Academy, Munich. He served as member of the Editorial Board of the Encyclopedia of American Studies Online and is general editor (with Miles Orvell, Jeffrey Meikle, and David Nye) of "Architecture/ Technology/Culture" (ATC), a monograph series published by the University of Pennsylvania Press.

Major publications include: Rethinking the American City: An International Dialogue (editor/2014); Culture and Mobility (editor/2013); Scientific Cultures Technological Challenges: A Transatlantic Perspective (editor/2009); The Power and Politics of the Aesthetic in American Culture (editor/2007); Space in America: Theory, History, Culture (editor/2005); African Diasporas in the New and Old Worlds: Consciousness and Imagination (editor/2004, second edition 2006); The Sea and the American Imagination (editor/2014); Romantic Cyborgs: Authorship and Technology in the American Renaissance (2002/paperback 2010). 
Françoise Dupeyron-Lafay is Professor of Nineteenth-Century Literature at Université Paris Est Créteil (UPEC); she has published widely on De Quincey and Victorian writers (Dickens, Wilkie Collins, J.S. Le Fanu, H.G. Wells, and A. Conan Doyle), and has focused on the cross-fertilization between genres, representations of urban spaces, and on questions of style and poetics. She is the author of $L e$ Fantastique anglo-saxon (1998), has translated George MacDonald's Lilith (1895) into French in 2007, and published a monograph on De Quincey's autobiographical works titled L'Autobiographie de Thomas de Quincey. Une Anatomie de la douleur (2010).

Andrew Estes is originally from Nashville, Tennessee, and now teaches American literature and history at LMU, Munich. He earned his BA at the University of Georgia, his Master's at Johns Hopkins, and completed his PhD at the University of Munich in 2011. His dissertation treats environmental criticism and Cormac McCarthy; it was published in 2013 in the series "Spatial Practices" at Editions Rodopi.

Juliette Fabve holder of the "agrégation" in French literature, is now completing her $\mathrm{PhD}$ on the "promenade" in French literature during the eighteenth century, at the Sorbonne University (Paris-IV), under supervisor Professor Michel Delon. In her research she focuses on dialogue, walking, and literature during the modern period.

Gabrielle Finnane is Lecturer in Asian Media Art and Environmental Media at the University of New South Wales' School of Art and Design, Australia. She is a filmmaker. Her films include I, Eugenia (1998). She has exhibited photography and video and collaborated on the multimedia installation If on a Tropic Night (2010). She has produced two documentary films in the Philippines (both directed by Robert Nery) - Black Nazarene (2003) and In 1966 the Beatles Came to Manila (2013). She has published criticism on cinema and video art and wrote her doctoral thesis on "Walking, Place-making and the Moving Image."

Andrew Goodman is a visual artist whose practice encompasses sculpture, sound, interactive technologies, and performance. He writes on art and process philosophy and is a postdoctoral researcher at the University of New South Wales.

Andrew Gross is Professor of American Literature at the Georg-AugustUniversität Göttingen. Recent publications include The Pound Reaction: Liberalism and Lyricism in Midcentury American Literature (2015), which contains a version of this article, an essay in The European Journal of American Studies 9.2 (2014) on "Commerce and Sentiment in Tales of Barbary Encounter," and a contribution to The Post-2000 Film Western (ed. Marek Paryż. New York: Palgrave Macmillan, 2015) entitled "Post-Apocalyptic Prophecy: The Book of Eli's Vision of a Forgotten Future." 
Marie Mianowski is associate professor at the University of Nantes where she teaches contemporary literature in English, as well as literary translation. She has published many papers on Irish contemporary literature. In 2012, she edited Irish Contemporary Landscapes in Literature and the Arts (Palgrave Macmillan) and she is preparing a book on Colum McCann, William Trevor, Dermot Bolger, Anne Enright, Claire Kilroy, and Donal Ryan (Post Celtic-Tiger Landscapes in Irish Fiction since 2008 to be published by Ashgate, 2016). Her research interests are Irish studies, the representations of exile, space, and landscape in contemporary literature and the arts.

Amélie Moisy is maître de conferences (associate professor) in Applied Languages at the Université Paris Est Créteil. A member of the research group in literature TIES/IMAGER and of the Thomas Wolfe Society, she is the author of a doctoral thesis, of numerous articles, and of a book on Thomas Clayton Wolfe (Thomas Wolfe, L'épopée intime, 2002). Her work on Wolfe has drawn her to other Southern writers of the USA of the 1930s and 1940s, notably Eugene Caldwell and Marjorie Kinnan Rawlings; she has also published articles on nineteenth-century writers and contemporary American writers.

Sarah Mombert teaches nineteenth-century French literature at ENS Lyon and is a member of IHRIM (CNRS-Université de Lyon). Her work focuses on journalism, popular culture, and the relationship between literature and history. She is the editor of the online edition of Alexandre Dumas's newspapers (alexandredumas.org).

Estelle Murail holds a joint-supervised $\mathrm{PhD}$ in English Literature from the Université Paris-Diderot and King's College London. She has taught English literature and translation at Université Paris-Diderot, Paris Est Marne-La-Vallée and at Sciences-Po Paris. Her PhD examined the figure of the flâneur in London and Paris. It is entitled "Beyond the Flâneur: Walking, Passage and Crossing in London and Paris in the Nineteenth-Century." She co-teaches the seminar "Victorian Persistence" with Professor Sara Thornton and is currently teaching English at the Lycée Saint-Jean de Passy in Paris.

Julien Nègre is Associate Professor of American Literature and Culture at the École Normale Supérieure de Lyon (Université de Lyon, France) and a member of IHRIM (CNRS). His research focuses on the place of maps and mapping in American literature. His $\mathrm{PhD}$ dissertation examined the role of cartographic thinking in Henry David Thoreau's writings, from his early essays to his posthumous texts on seeds and wild fruits. He has published articles on the place of maps and geography in the writings of William Byrd of Westover, Herman Melville, Henry David Thoreau, Jack Kerouac, and Thomas Pynchon.

Emmanuelle Peraldo is Senior Lecturer in British Eighteenth-Century Literature at the University Jean Moulin, Lyon 3, and member of the IETT (Institut d'Etudes 
Transtextuelles et Transculturelles, EA 4186). Her current research focuses on the link between geography and literature in the early modern period, and, more particularly, in Daniel Defoe. Her most recent publications are an article co-written with a geographer (Yann Calbérac) "How to do narratives with maps? Cartography as a performative act in Gulliver's Travels and Through the Looking-Glass" (Reconstructions, 2015), and a translation in French of Defoe's Caledonia (Honoré Champion, 2016).

Tatiana Pogossian holds a PhD in English studies from the Université ParisDiderot. She compared works by Iain Sinclair, Peter Ackroyd, and Gilbert \& George in order to make out the ways in which urban experience dictates and informs specific modes of re-presentation of wandering in London. So far her research has explored the means to unveil London's past and the extent to which these means question the very notion of empiricism. Her papers have tackled the issues of representation, ranging from modernism to postmodernism, from iconography to ecocriticism or psychogeography regarding contemporary British fiction or British arts.

Thomas Pughe teaches British and American literature at the University of Orléans, France. His main research interests are ecocriticism, ecopoetry, and animal studies.

Virginia Ricard is an associate professor at the University of Bordeaux Montaigne. Her recent publications include "La Conviction jubilatoire d'Edith Wharton" (Modernités 39 [2015]) and the edition of a special issue of The Journal of the Short Story in English devoted to the stories of Edith Wharton (2012).

Lacy Rumsey is Associate Professor of English at the Ecole Normale Supérieure de Lyon and a researcher affiliated with the CNRS (IHRIM). He works on twentieth- and twenty-first-century American and British poetry, with a particular emphasis on prosody. His recent essays include studies of the role of intonation in poetic form, of the reappropriation of metre in the work of the contemporary British poet Jeff Hilson, and of monuments and monumentality in the poetry of Jonathan Williams and Ronald Johnson. He is writing a book-length study of the prosody of non-metrical poetry.

Bridget Sheridan is a researcher in visual arts. Her research investigates the relationship between art walking, the landscape, and memory.

Besides teaching Art at Jean Jaurès University in Toulouse, her own artwork has been exhibited by various galleries and art centers in Europe.

François Specq is Professor of American Literature and Culture at the École Normale Supérieure de Lyon (Université de Lyon) and a researcher affiliated with the CNRS (IHRIM). He has published critical studies and translations of works by Thomas Jefferson, Henry David Thoreau, Ralph Waldo Emerson, Herman 
Melville, Frederick Douglass, Margaret Fuller, and Mary Austin, and essays on American aesthetics of the colonial period and the nineteenth century (visual culture, painting, music). He is co-editor of Thoreauvian Modernities: Transatlantic Conversations on an American Icon (2013), and editor of Environmental Awareness and the Design of Literature (Leiden: Brill, forthcoming).

Sophie Walon received a four-year scholarship from ENS Lyon after graduating with a multidisciplinary BA from Lycée Henry IV (Paris). She holds a master's degree in philosophy (from ENS Lyon) and in film studies (from the University of Oxford). She is currently completing her doctoral research on representations of the body in dance films at ENS Paris. She also lectures on film theory and history at the Ecole Normale Supérieure and the Institut d'Etudes Politiques in Paris.

Catherine M. Welter is a doctoral candidate and dissertation fellow at the University of New Hampshire, where she specializes in Victorian literature. She holds a Master's degree from the University of Connecticut and a BA from Union College in New York. She is working on her dissertation, which applies a feminist disability studies lens to embodiment and mobility in several kinds of Victorian fiction, including detective fiction and fiction for children. 



\section{List of Figures}

Fig. 1 From Charles Olson, The Maximus Poems (150) 69

Fig. 2 From Jonathan Williams, Blues \& Roots 1985

Fig. 1 Marianne Colston, plate 24, The Bridge over the Adour, at Bayonne, June, 61821 (Reproduced with kind permission from the Bibliothèque de Toulouse)

Fig. 2 Marianne Colston, plate 47, Marignac, near St Beat. Haute Garonne. October, 41821 (Reproduced with kind permission from the Bibliothèque de Toulouse)

Fig. 3 Marianne Colston, plate 19, ${ }^{\circ}$ The British Library Board. Marianne Colston, Plate 19, The Last Fall of the Reichenbach in the Valley of the Hasli. Oct., 5 1820. (762.g.11)

Fig. 4 Marianne Colston, plate 13, Martigny in the Canton of the Valais. September, 23 1820. ${ }^{\circ}$ The British Library Board

Fig. 1 Patricia Lefèbvre, La femme qui marche, 3 pinholes from a series of 8 , each $40 \mathrm{~cm} \times 50 \mathrm{~cm}, 2010$

Fig. 2 Aileen Harvey, West from Here, Howmore 000010062010 , from a series of 17, C-type print mounted on aluminum, $35 \times 33 \mathrm{~cm}, 2010$

Fig. 3 Tarbet (Sutherland), three black-and-white prints from pinhole negatives, each $24 \times 24 \mathrm{~cm}, 2013$

Fig. 4 Bridget Sheridan, Kerfany Walk, artist's book, 2012

Fig. 1 Gilbert \& George, JESUS SAID (2001) ${ }^{\circ}$ the artist

Fig. 1 Untitled Compressionism scan, Nathaniel Stern \& 